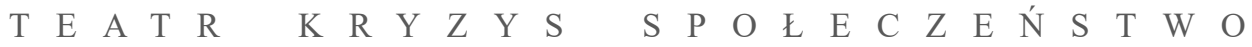

PAMIĘTNIK TEATRALNY 2020/4 (276)

ISSN 0031-0522, e-ISSN 2658-2899

INSTYTUT SZTUKI PAN

DOI: $10.36744 /$ pt.368

\title{
Tomasz Kubikowski
}

Akademia Teatralna im. Aleksandra Zelwerowicza w Warszawie

ORCID: 0000-0002-1028-9624

\section{PRZESTRZEŃ EMBLEMATYCZNA}

\author{
Emblematic Space
}




\begin{abstract}
Abstrakt: W artykule autor śledzi związki sztuki teatru ze sztuką emblematu. Wychodząc od dzieł Albrechta Schönego i posiłkując się współczesną teorią emblematu, stawia tezę, że obydwie sztuki wykorzystują zjawisko performansu, z którym wiążą się nierozerwalnie. Strukturę emblematyczną można odnaleźć zarówno w trwałych zaczątkach teatralnego performansu (dramat lub scenariusz), jak i w jego pozostałościach (dokumenty dzieła). Emblemat stanowi więc ostateczne medium oddziaływania teatru na najdalszy społeczny dystans, kiedy zanikł wszelki żywy kontakt odbiorców ze zjawiskiem. Teatr szczególnie nastawiony na społeczną misję, najchętniej sięga do środków sztuki emblematu. Tytułowa „przestrzeń emblematyczna” - to abstrakcyjna kategorialna przestrzeń, którą ustanawia i w której zachodzi performans życiowy, społeczny czy sceniczny. Otwiera się ona w powszechnej świadomości jako jego „scena”. W teatrze takie przestrzenie powołuje się programowo; w życiu powszednim tworzą się one samorzutnie, jako emanacje zbiorowych oczekiwań lub nadziei, albo poprzez działania jednostek.
\end{abstract}

Słowa kluczowe: performatyka, emblemat a teatr, teatr społeczny, teoria emblematu

\begin{abstract}
In this paper, the author traces the connections between the art of the theater and the art of the emblem. Revisiting the work of Albrecht Schöne and referring to the present theories of the emblem, the author claims that both art forms employ performance, which inseparably connects them. Emblematic structures can be found both in the beginnings of a theatrical performance (the play or the script) and in its remains (the documentation of the performance). The emblem is therefore the ultimate medium of the theater's influence and transmission at the longest social distance, when any direct link of the audience with the original performance has already vanished. We can observe that theater more oriented towards social impact tends to utilize emblematics all the more willingly. Finally, the author introduces the notion of the "emblematic space": an abstract categorial space, which is constituted and transformed through performance, containing it as its "stage." Theater's task is creating such spaces; in everyday social life, they arise spontaneously as emanations of the collective hopes or expectations; they are also set up by individual efforts. (Trans. T. Kubikowski)
\end{abstract}

Keywords: performance theory, theater emblematics, social theater, emblem theory 
Tak więc emblematyka i ikonologia stały się pod koniec XVII wieku punktem wyjścia do z e s p o le n i a wszelkich sztuk, jakie ludzie uprawiają.

Władysław Tatarkiewicz, Historia estetyki ${ }^{1}$

G

esamtkunstwerk! Tatarkiewicz przypisuje sztuce emblematu coś, do czego rościł sobie pretensje teatr: w arcysławnej wizji Richarda Wagnera ${ }^{2}$, w marzeniach teatralnej kontrkultury o ,więcej niż teatrze”, przede wszystkim zaś w pielęgnowanym przez tysiąclecia śnie o (trójjedynej) chorei - źródłowym, utraconym zespoleniu wszechsztuk, wszechprzekazów i wszechekspresji; śnie, który od początków nowożytności inspirował kolejne fale reformatorów i odnowicieli. Konkurencja sztuki emblematu i sztuki teatru na tym polu skłania zatem do zastanowienia.

Około połowy XX wieku ożywiło się - przygasłe od dwóch stuleci - zainteresowanie emblematem. O jego historii, budowie i działaniu napisano wówczas dzieła, które dziś uchodzą w tej dziedzinie badań za założycielskie. Impuls dał im jeszcze w roku 1930 Mario Praz, ogłaszając Studi sul concettismo³. W 1959 opublikowano w Reallexikon zur Deutschen Kunstgeschichte ważne i szeroko potem komentowane hasło „Emblemat” autorstwa Williama Heckschera i Karla-Augusta Wirtha ${ }^{4}$. W latach sześćdziesiątych - kiedy Tatarkiewicz formułował swą ocenę historycznej roli emblematyki - Albrecht Schöne wydał Emblematik und Drama im Zeitalter des Barock (1964) oraz - wspólnie z Arthurem Henklem - Emblemata.

1 W. Tatarkiewicz, Historia estetyki, Wrocław 1967, t. 3, s. 268.

2 R. Wagner, Sztuka i rewolucya, przeł. J. Mesnil, Lwów 1904, s. 11. Warto zauważyć, że szeroki sens, jaki Wagner nadawał pojęciu Gesamtkunstwerk, został sprowadzony do wymiaru czysto strukturalnego w polemice Craiga, za którym przejęła tę interpretację kształtująca się na początku XX w. w duchu craigowskim polska teatrologia. Jako ilustrację tego zjawiska por. S. Skwarczyńska, Narodziny i drogi rozwojowe polskiej teatrologii, [w:] Wprowadzenie do nauki o teatrze, red. J. Degler, Wrocław 1976, t. 1, s. 35-44, zwłaszcza s. 38-39.

3 Zostało ono spopularyzowane później w angielskim przekładzie z 1939. Praz rozwijał to dzieło jeszcze przez dziesięciolecia po pierwszym wydaniu. Por. idem, Studies in Seventeenth-Century Imagery, Roma 1964.

4 Por. W. S. Heckscher, K. A. Wirth, Emblem, Emblembuch, [w:] RDK Labor, http://www.rdklabor.de/w/?oldid=93191 [dostęp: 17 IV 2020]. 
Handbuch zur Sinnbildkunst des XVI. und XVII. Jahrhunderts (1967)5. Pierwsze $\mathrm{z}$ tych dzieł nadal stanowi podstawowy punkt odniesienia, gdy idzie o funkcjonowanie emblematu w teatrze; obydwa zaś - ustanowiły wyrazisty model interpretacji całej ars emblematica, którego podstawowe założenia powiela się, dyskutuje bądź kontestuje do dziś.

W tej samej dekadzie nastąpił zresztą wysyp studiów poświęconych emblematom, wśród nich pierwsze publikacje Janusza Pelca, który później stał się u nas czołowym znawcą i propagatorem spraw emblematycznych, autorem dwóch podstawowych książek na ten temat. Podsumowujące jego twórczość Stowo i obraz $(2002)^{6}$ do dziś pozostaje najpełniejszym opracowaniem kwestii emblematu na rodzimym gruncie. Pelcowi zawdzięczamy też sumienne relacje na temat stanu i rozwoju badań nad emblematyką na świecie i w Polsce. Janowi Białostockiemu zaś - pamiętną wystawę „Ars emblematica. Ukryte znaczenia w malarstwie holenderskim XVII wieku” w Muzeum Narodowym w Warszawie (1981) ${ }^{7}$. Od 2002 można też czytać po polsku Książeczkę emblematów Andrei Alciatiego ${ }^{8}$ - czyli dzieło, od którego w XVI wieku wziął nazwę cały omawiany gatunek słowno-ikonicznego przekazu i które stanęło u podstaw późniejszej „emblemanii”, osiągającej apogeum w wieku następnym.

Autorem najświeższego bodaj sumarycznego sprawozdania z powszechnego stanu badań nad emblematyką (2014) jest Peter M. Daly, który od lat siedemdziesiątych ubiegłego wieku walnie przyczynił się do ich rozwoju. Inicjował i prowadził szerokie poszukiwania źródłowe, pisał i redagował książki ${ }^{9}$, a w połowie lat osiemdziesiątych, wraz z Danielem S. Russellem, założył czasopismo „Emblematica". Jak pisze Daly:

Doszło do swoistego rozkwitu w dziedzinie studiów nad emblematami. Szacuję, że tylko w dwudziestoleciu 1990-2010 opublikowano w językach zachodnioeuropejskich około tysiąca czterystu artykułów, rozpraw i książek poświęconych emblematyce ${ }^{10}$.

5 Por. Emblemata. Handbuch zur Sinnbildkunst des XVI. und XVII. Jahrhunderts, hrsg. A. Henkel, A. Schöne, Stuttgart 1996.

6 J. Pelc, Stowo i obraz. Na pograniczu literatury i sztuk plastycznych, Kraków 2002.

7 B. Steinborn wymienia ją wśród trzech europejskich wystaw lat 1976-1981, dzięki którym „skonfrontowanie [...] obrazów z [...] literaturą (w tym z książkami emblematycznymi, którymi dotychczas zajmowali się historycy literatury) ujawniło ich ukryte [...] treści. Od czasu ogłoszenia tych muzealnych badań nie można już było w pracach nad dawnym malarstwem pomijać penetracji [...] literatury", eadem, Czy muzealnik jest naukowcem? Kilka uwag praktyka, „Muzealnictwo” 2014 nr 55, s. 20.

8 Zamiennie występującego też jako Alciato lub w zlatynizowanej formie: Alciatus. Por. A. Alciatus, Emblematum libellus. Ksiażeczka emblematów, przeł. A. Dawidziuk, B. Dziadkiewicz, E. Kustroń-Zaniewska, pod kier. M. Mejora, Warszawa 2002. Obszerny i wartościowy wstęp do edycji przygotował R. Krzywy.

9 P. M. Daly, Literature in the Light of the Emblem, Toronto 1998.

10 Idem, The Emblem in Early Modern Europe. Contributions to the Theory of the Emblem, London 2016, s. 12 [pierw. 2014]. Przekłady, jeśli nie zaznaczono inaczej, T. K. 


\section{HISTORYCZNE ZWIĄZKI TEATRU I ARS EMBLEMATICA WEDŁUG ALBRECHTA SCHÖNEGO}

Dyskusja na temat wielotworzywowej sztuki emblematu, z założenia interdyscyplinarna, toczy się zazwyczaj tylko pomiędzy specjalistami w dziedzinach sztuki i literatury. Nie myśli się wiele o emblemacie w kontekście jego ewentualnych głębszych pokrewieństw z teatrem. Pelc zaledwie wspomina, że: „kompozycja emblematyczna [...] służyła często w dobie baroku i potem także jako podstawa schematu budowy różnych gatunków dramatycznych i różnych typów ówczesnego teatru" "11, dalej zaś notuje, że:

Roli emblematyki oraz inspiracji emblematycznych w barokowym dramacie i teatrze niemieckim piękną książkę poświęcił Albrecht Schöne. Na podobne osobne opracowanie oczekuje wciąż barokowy dramat i teatr w Polsce. W pracy niniejszej, stawiającej sobie inne cele, nie możemy zadania tego spełnić. Ze względu jednak na ważną rolę, jaką w naszym barokowym teatrze i dramacie odegrały formy emblematyczne, nie możemy także spraw tych [...] pominąć czy zlekceważyć. [...] Poprzestaniemy jednak na ogólnym zarysie i wybranych ważniejszych przykładach $^{12}$.

I faktycznie na tym poprzestaje. Wiernie trzyma się listy emblematycznych znamion, wyodrębnionych i wskazanych czterdzieści lat wcześniej przez Schönego; odnajduje je w polskim teatrze barokowym. Opisuje zatem wszelkie: „personifikacje, alegorie, a także symbole emblematyczne [...] w sztukach wystawianych [...] na scenach kolegiów jezuickich"13. Odnajduje w ich tekstach utrwalone w zbiorach emblematów i stamtąd czerpane unaocznienia takie jak ,łzy krokodylowe". Wskazuje obyczaj zamykania poszczególnych scen kontrapunktującymi i podsumowującymi akcję sentencjami (które już Scaliger porównywał do podtrzymujących dramat kolumn), nieraz wprost przejmowanymi ze zbiorów emblematycznych. Nareszcie Pelc trafnie referuje, że:

Schöne analogi i strukturalnej w stosunku do emblematu dopatruje się w sposobie, w jaki w dramacie barokowym wiązano poszczególne akty z następującymi po nich chórami. Sam akt był odpowiednikiem imago, chór pełnił rolę komentującej obraz subskrypcji. W ramach tej analogii zbieżności konstrukcyjne zarysowują się szczególnie wyraźnie właśnie między wypowiedzią chóru a emblematyczną subskrypcją. Chór stawał się sygnifikacją, komentarzem słownym obrazu, jaki przedstawiał akt ${ }^{14}$.

Takie właśnie konstrukcje występowały również na polskich scenach.

11 J. Pelc, op. cit., s. 45.

Ibidem, s. 288.

Ibidem, s. 289.

Ibidem, s. 291-292. 
Zamiast zatrzymywać się nad dalszymi Pelcowymi wyliczeniami oczywistych znamion wpływu emblematów na teatr, lepiej cofnąc się do ich źródła - czyli do książki Schönego. Znaczną jej część zajmuje wykorzystany przez Pelca katalog cech emblematycznych barokowego teatru ${ }^{15}$. Schöne wskazuje w nim również częste w epoce baroku dwuczłonowe tytuły dramatów, tworzące emblematyczny układ, w którym część główna tytułu służy jako lemma, podtytuł zaś - jako subskrypcja (przy czym sama akcja sceniczna stanowi oczywiście imago). Za przykłady służą mu Katarzyna Gruzińska, czyli Stałość Uzbrojona oraz Leon Armeńczyk albo Zabójstwo Księcia Gryphiusa - ale wychodząc poza książkę Schönego i obszar niemiecki, można wymienić kolejne: Tartuffe albo Szalbierz Molière'a czy też Fałszywa stużaca, czyli Łajdak ukarany Marivaux. Wychodząc zaś poza epokę: Cud mniemany, czyli Krakowiacy i Górale Bogusławskiego, Śluby panieńskie, czyli Magnetyzm serca Fredry. Emblematycznych tytułów naprawdę jest bez liku.

Schöne wyodrębnia też w mowie specyficzną konstrukcję, którą nazywa genetivus emblematicus: abstrakt trwale upostaciowany swoim emblematycznym atrybutem tak, że tworzy to pewną zbitkę językową, w której sam abstrakt pozostaje zawsze w dopełniaczu - np. „skrzydła odwagi”, ,żmija zazdrości”, „płomień miłości”. Podobna konstrukcja językowa często powtarza się w mowie ozdobnej, w tym i w dramatach. Inny jeszcze występujący w siedemnastowiecznych sztukach retoryczny konstrukt to argumentum emblematicum: postaci dramatyczne powołują się na wyobrażone w emblematach sytuacje lub obrazy jako na uznane fakty (przynajmniej fakty kulturowe), uzasadniające racje bohaterów lub też wykazujące fałsz ich antagonistów. Tak na przykład - znów wychodząc poza zakres egzemplifikacji z książki Schönego - Hamlet, zuchwale odpowiadając Klaudiuszowi w drugiej scenie trzeciego aktu tragedii, mimochodem powołuje się na znany wszystkim emblematyczny obraz kameleona jedzącego powietrze, w tym wypadku: „,nadziane obietnicami”.

Katalog Schönego, jakkolwiek użyteczny, wyczerpujący i wielokrotnie wykorzystywany przez historyków teatru, brzmi sucho i może nawet budzić podejrzenia, czy autor nie za daleko posunął emblematyczne skojarzenia i czy rozciągnięcie ich od figur stylistycznych aż na strukturę dramatu nie jest nadużyciem. W każdym zaś razie katalog daje wrażenie, że charakteryzujemy tylko pewną osobliwość barokowej poetyki, szczególną - jakby to określił Praz - „kaligrafię”16 zamierzchłej epoki.

15 Ta część książki jest w Polsce najlepiej znana, jako że przed Pelcem streścił ją już - w 1969, wtedy jako nowość - i oparł na niej cały rozdział swej książki M. Szyrocki, zob. idem, Dzieje literatury niemieckiej, t. 1, Warszawa 1969, s. 175-184.

16 M. Praz, Mnemosyne. Rzecz o powinowactwie literatury i sztuk plastycznych, przeł. W. Jekiel, Warszawa 1981, s. 30. 
I jest to zapewne wrażenie błędne. U podstaw moich rozważań leży właśnie podejrzenie, że sztukę teatru łączą ze sztuką emblematu więzi głębsze i ponadczasowe, że są to więzi tyleż strukturalne, co funkcjonalne, i że przejawiają się one szczególnie w społecznym funkcjonowaniu jednej i drugiej sztuki. Spróbuję rzeczone więzi rozpoznać i nazwać. Proponuję w tym szkicu rozpoznanie wstępne: nie oddam więc sprawiedliwości całej ogromnej literaturze przedmiotu, lecz oprę się na wybranych, najbardziej instruktywnych źródłach, pozwalających myśli postępować bez poczucia, że pominęło się istotny argument czy też nić rozumowania.

Wychodzę od książki Schönego, jako do dziś nieprześcignionej. Tezy Schönego reinterpretuję, posługując się instrumentarium pojęciowym powstałym już po opublikowaniu jego dzieła; odwołam się też do świadectw z omawianej przez niego epoki. Reinterpretacja stanie się następnie podstawą rozważań nad związkami sztuki emblematu z performansem - tak jak go pojmuję. Na gruncie performansu szukam powinowactw emblematu z teatrem, by ostatecznie sformułować myśl o emblemacie jako możliwym medium oddziaływania teatru na najszerszą społeczną skalę. A nawet szerzej - jako o medium najdalszego, w czasie i przestrzeni, przekazu ludzkiego performansu.

\section{SCHÖNEGO KONCEPCJA EMBLEMATU}

Trzeba zatem od razu cofnąć się do zasadniczej - z jednej strony kanonicznej, z drugiej zaś nieustannie podważanej - koncepcji emblematu, która u Schönego poprzedza i uzasadnia morfologię barokowej teatralnej emblematyki. Już w 1968 jego propozycje zakwestionował wybitny holenderski badacz Hessel Miedema ${ }^{17}$. Z drugiej strony Daly przyznaje jednak w 2014, że „teoria Schönego wciąż daje nam najlepszy ogólny zarys, obejmujący aspekty formalne, ontologiczne, semantyczne, funkcjonalne i intencjonalne"18.

Uznając obfitość i różnorodność historycznych form emblematu, Schöne za punkt odniesienia bierze jego konstrukcję trójczłonową (emblema triplex). Na emblemat składają się wtedy: inscriptio (inne nazwy: lemma, motto), pictura (imago, eikon) oraz subscriptio (epigramma). Jak wyjaśnia autor: „sensowne wydaje się tutaj tylko opisanie centrum, określenie typu idealnego, z którego wychodząc, będzie można usystematyzować całą obfitość mniej lub bardziej peryferyjnych

17 Por. H. Miedema, The Term Emblema in Alciati, ,Journal of the Warburg and Courtauld Institutes" vol. 31 (1968), s. 234-250. Miedema - jak sam Schöne i wielu po nim - podważa koncepcje antagonistów (także Heckschera i Wirtha), znajdując nieodpowiadające im konkretne exempla u Alciatiego.

18 P. M. Daly, The Emblem..., op. cit., s. 36. 
postaci emblematu"19. Nie pierwszy Schöne tak uczynił: podobna budowa emblematu została uznana za kanon już w XVII wieku przez Claude-François Ménestriera - do którego odnosi się Tatarkiewicz i szereg innych autorów z Pelcem włącznie. Może to jednak brzmieć restrykcyjnie.

Sam Alciati przecież z początku wcale nie ilustrował swoich emblematów zrobił to za niego wydawca. Trójczłonowa forma ucierała się przez dłuższy czas, zanim ją Ménestrier unormował. Nieustannie funkcjonowały też w druku pozbawione obrazów emblemata nuda. W innych z kolei emblematach słowo, choć połączone $\mathrm{z}$ obrazem, nie zawsze występowało w postaci dwóch różnych tekstów dających się jednoznacznie przyporządkować wyznaczonym funkcjom lemmy i subskrypcji. Kiedy zaś wyjdziemy poza dziedzinę emblematów drukowanych w stronę dzieł, w których poszczególne człony emblematu można odnajdywać raczej poprzez analogię - rzecz komplikuje się niepomiernie.

Alciati nie zdefiniował wielotworzywowego gatunku; stworzył go niejako mimochodem. „Emblemata” traktował tylko jako tytuł własnych dziełek. Zainspirowany przez niego i jego wydawców proceder intrygującego zderzania ze sobą obrazu i różnych rodzajów słowa rozwinął się jednak potem żywiołowo. W XVII wieku łączny nakład książek zawierających emblematy Daly liczy bez mała w miliony - co gdy zważyć ogólną ówczesną skalę wydawnictwa i czytelnictwa, stanowi liczbę oszołamiającą ${ }^{20}$.

Emblematyczny proceder rozwinął się poza czyjąkolwiek kontrolą i, przybierając wiele odmian i odcieni, rozplenił się w rozmaite domeny ludzkiej twórczości - aż właśnie do teatru włącznie. „Być może nadszedł czas na syntetyczną definicję emblematu" ${ }^{21}$ - nawoływał w 1998 Daly, jednakże do tej pory takiej ścisłej, niekwestionowanej definicji nie doczekaliśmy się i w późniejszej swej książce ten sam autor również już do niej nie wzywa. Miast tego pisze z przekąsem, że „skoro możemy wybierać spośród ponad 6500 ksiąg emblematów [...], nietrudno dobrać jakąś książkę na podparcie wszelkich twierdzeń krytyków”22.

Zdaniem krytyków Schönego proponowany przez niego „typ idealny” stanowi z gruntu arbitralny wymysł, który raczej zawęża, zniekształca i zubaża pole dociekań, niż je porządkuje. Od strony metodologicznej jednak zabieg Schönego jest całkowicie zrozumiały. W przypadku bowiem zbioru rozmytego - a tak niewątpliwie należy traktować zachowane emblematy wszelkiego rodzaju - wyróżnia się jego rdzeń, czyli te elementy, których przynależność do zbioru jest niewątpliwa i całkowita: właśnie owo „centrum” Schönego.

\footnotetext{
19 A. Schöne, Emblematik und Drama im Zeitalter des Barock, München 1964, s. 29.

20 Por. P. M. Daly, The Emblem..., op. cit., s. 43.

21 Idem, Literature..., op. cit., s. 7.

22 Idem, The Emblem..., op. cit., s. 120.
} 
Trzeba też pamiętać, że we wczesnej nowożytności emblematyka kwitła w gęstym otoczeniu form pokrewnych i konkurencyjnych: starszej od siebie heraldyki, pochodnej od siebie ikonologii czy popularnej w epoce odrodzenia hieroglifiki. Alegoria, ekfraza, hypotypoza, symbolika - jako różnorakie środki wyrazu i mimesis, środki łączenia obrazu z werbalnym sensem oraz tworzenia obrazu poprzez werbalne sensy i na odwrót - kłębiły się w tej samej co emblemat przestrzeni, przenikały się, wspierały i wzajem zastępowały. Wokół emblematu panował ścisk form mniej lub więcej pokrewnych, a w takim tłoku wszelkie linie demarkacyjne są tyleż wątpliwe, co przydatne. Jeszcze zaś przydatniejsze są wyraźnie zaznaczone punkty orientacyjne, jakieś choćby umowne „centra”, pozwalające w przybliżeniu stwierdzić, w jakiej domenie się znajdujemy, zajmując się konkretnymi przykładami.

Wydaje się, że właśnie owo „centrum” - Schönowski ,ideał”, by nie rzec istotę - tworu zwanego „emblematem”, cechę charakterystyczną wszystkich elementów omawianego zbioru stanowi zderzenie w emblematach kilku zupełnie odmiennych sposobów określenia, przedstawienia bądź nawiązania do tego samego. Może to być obraz i słowo albo różne rodzaje słów czy charakterystyki językowej. Ale też miejsce obrazu może brać żywa akcja sceniczna, która z kolei może się zderzać i z obrazem, i ze słowem w rozmaitych jego postaciach... heterogenicznych kombinacji jest bez liku. Heterogeniczność zdaje się kluczem do emblematu.

Może zatem podstawowym błędem Schönego było użycie mocno wartościującego przymiotnika „,idealny”, przez który łatwo zakwestionować bezstronność jego analizy. Gdyby w zamian użyć epitetu czysto metodologicznego - mówić na przykład o typie „,normatywnym”, „zasadniczym” czy „standardowym”; gdyby podkreślić techniczny charakter zabiegu i jego umowność - być może aż takiej awantury by nie było.

Uwaga ta dotyczy po części także drugiego filaru koncepcji Schönego. Jak pisze autor (pamiętajmy, że przez „subskrypcję” i „epigram” rozumie on to samo):

$\mathrm{W}$ stosunku do [...] epigramu [...], emblematycznej pictura przynależy istotowo odmienny poziom rzeczywistości: ona i przede wszystkim ona reprezentuje całkiem bezpośrednio - jako że naocznie - pewien element rzeczywistości, mniej lub bardziej zręcznie przedstawiony przez twórcę obrazów i potem wyłożony poprzez subscriptio [...]. Każdy emblemat przyczynia się do wyjaśnienia, wytłumaczenia i wykładni rzeczywistości. Obojętnie zatem, czy - jak u Alciatiego - najpierw była subskrypcja, [...] czy też tak jak późniejsi emblematycy wychodzi się od pictura i do niej dopasowuje się epigram: poprzez subskrypcję emblemat nadaje znaczącemu obrazowi sens, tym samym zmuszając obserwatora i czytelnika do uznania pierwszeństwa obrazu${ }^{23}$.

23 A. Schöne, op. cit., s. 25. 
I już bez żadnych dodatkowych objaśnień owo postulowane pierwszeństwo również nazywa się, ledwie dwie strony później, „idealnym”. Takie określenie budzi wątpliwości nawet na tle literatury epoki. Platońskie czy zachowujące ducha średniowiecza interpretacje emblematu przypisywały bowiem pictura funkcję „ciała” emblematu: ciała naocznie, materialnie postrzeganego; podczas gdy bardziej z natury wyabstrahowane określenia słowne, zwłaszcza lemma, miały być emblematu „duszą”. Świadectw podobnego pojmowania jest wiele, sam Schöne je przytacza ${ }^{24}$ i nie zauważa, że przecież według nich emblemat mógłby się ewentualnie zbliżać do ideału właśnie swą przeciwną niż pictura stroną.

W sumie więc - jakkolwiek teza o ideelle Priorität des Bildes stanowi kolejny filar koncepcji Schönego - trudno byłoby ją utrzymać w pełnym brzmieniu, jeśli miałaby mieć szeroką moc obowiązywania. Gdyby jednak także jej odjąć „idealność" - gdyby mówić zamiast tego ledwie o „domniemanym” czy też „faktycznym” pierwszeństwie obrazu w emblemacie? Zauważmy dwie poboczne tezy, którymi w cytowanym fragmencie tezę o Priorität des Bildes się uzasadnia. Pierwsza: emblemat służy poznaniu i interpretacji rzeczywistości; jest narzędziem poznawczym. Druga: obraz znajduje się bliżej owej rzeczywistości niż tekst; reprezentuje ją „całkiem bezpośrednio”. To właśnie może dawać mu pierwszeństwo.

W dziedzinie teatru sojusznikiem Schönego co do tej ostatniej sprawy mógłby okazać się Arystoteles. Schöne bowiem uznaje akcję dramatyczną za odpowiednik pictura, Arystoteles zaś w trzecim rozdziale Poetyki (1448a) przyznaje jej pierwszeństwo przed tekstem. Tyle że Arystoteles traktuje to pierwszeństwo czysto strukturalnie, jako wyróżnik gatunkowy dramatu - nie w odniesieniu do jakiejkolwiek prześwitującej za dramatem prawdy.

Pora na trzeci zasadniczy filar koncepcji Schönego, myśl podsumowującą poprzednie:

Widać więc, że emblematyczna pictura i współdziałające z nią w dziele obrazowania tekstowe części emblematu przedstawiają coś, co rzeczywiście istnieje lub jest w przyszłości możliwe; coś z rzeczywistości, która choć nie zawsze - albo może: jeszcze nie - ukazuje się naszym oczom, zawsze jednak może wejść w ludzkie pole widzenia. Obok zatem idealnego pierwszeństwa emblematycznej pictura (wobec subscriptio), i w dodatku jako warunek tego pierwszeństwa, emblemat ustanawia pewną potencjalną fak tyc zność ${ }^{25}$.

24 Ibidem, s. 179.

25 Ibidem, s. 27. 
Najzacieklej tę myśl krytykował Bernhard F. Scholz w przekrojowej książce Emblem und Emblempoetik (2002) ${ }^{26}$. Scholz odnosi jednak ,potencjalną faktyczność" głównie do sfery przedmiotów obrazu (res picta), stosując ją wprost do zawartych tam obrazów mitologicznych i thumacząc Schönemu, że odbiorcy w XVI i XVII wieku doskonale orientowali się, iż mityczne twory stanowią ludzki wymysł, nie mogli zatem dopuszczać ich realności, nawet potencjalnej ${ }^{27}$. Jasne tu jest, że Scholz dezinterpretuje tezę Schönego, rozumiejąc ją tylko jako przeświadczenie o potencjalnej faktyczności res picta. Tymczasem Schöne nie wmawia przecież naszym przodkom czasu Jagiellonów i Wazów przekonania, iż hydra lernejska może faktycznie pewnego dnia zaistnieć, albo, że kiedyś naocznie objawi im się uskrzydlona stopa na żółwiu, oglądana w Peristromie XVII Andrzeja Maksymiliana Fredry ${ }^{28}$. Nie o tę faktyczność Schönemu szło. Sam to zresztą explicite thumaczy. $\mathrm{O}$ co mu szło zatem?

\section{OBRONA TEZ SCHÖNEGO POPRZEZ ICH REINTERPRETACJE}

Spróbujmy obrony - nie tyle może ścisłych sformułowań, ile stojących za nimi, jak się zdaje, intuicji Schönego. Półżartem można powiedzieć, że jesteśmy mu to winni jako pierwszemu rzecznikowi teatru na terenie emblematyki. Poważnie zaś można powiedzieć, że jego rozpoznania chyba nie przypadkiem zachowały już półwieczną żywotność i wciąż niepokoją. Być może właśnie wykroczenie poza dominujący do dziś na terenie emblematyki duopol literatura-sztuki wizualne, pozwoliło Schönemu rozszerzyć spojrzenie na emblemat jako na międzygatunkowe czy wręcz ponadgatunkowe zjawisko kulturowe. Przede wszystkim zaś po-

26 W części ,systematycznej” tego dzieła trudno znaleźć wątek, który nie rozwijałby się w stałym, gwałtownym sprzeciwie wobec Schönego i nie wyrastał z zanegowania jego rozpoznań. Od rozpoznań przechodzimy czasem zresztą i do osoby - jak w pomieszczonym w przypisie Scholza wykrzykniku, że „,esencjalistyczno-wartościująca” terminologia Schönego (idzie oczywiście o sławetną ,idealność”) „więcej nam powiada o mówcy niż o przedmiocie rozmowy”. Zob. B. F. Scholz, Emblem und Emblempoetik. Historische und systematische Studien, Berlin 2002, s. 248.

27 Skądinąd ledwie stronicę wcześniej Scholz gromi adwersarza za to, że chcąc pojąć strukturę i funkcję emblematów, uzasadnia on swe rozpoznania, odwołując się do poetyk z epoki; ironicznie pisze, że równie dobrze Schöne mógłby odwołać się do przyrodniczych traktatów tejże epoki i nimi dowodzić prawdziwości wadliwie przedstawianej na dawnych rysunkach budowy ciała zwierząt. Ten ostatni zabieg polemiczny jest sam w sobie krzycząco niesłuszny, albowiem jasne, że w naukach przyrodniczych inaczej pojmuje się postęp niż w humanistycznych i że niegdysiejsze mniemania na temat, powiedzmy, stosunków semantycznych nie muszą z założenia być gorsze od mniemań dzisiejszych, podczas gdy anatomię zwierząt znamy faktycznie lepiej. Tym bardziej nie można samemu powoływać się na mniemania odległej epoki, chwilę wcześniej ganiąc innego, że się na nie powołuje. Zob. ibidem, s. 251 i nast.

28 Zob.http://polishemblems.uw.edu.pl/index.php/pl/e-zbiorypl/31-pierwszy-e-zbior/127-fredro-pl [dostęp: 13 XI 2020]. 
zwoliło na próbę uchwycenia wskazanego przez Tatarkiewicza aspektu: aspiracji emblematu do tego, by dać podstawę uniwersalnemu dziełu wszechsztuk.

Sformułowania, do których doszedł Schöne - przy wszystkich ich brakach, z nieroztropnym szafowaniem ,idealnością” na czele - byłyby wówczas próbą wysłowienia wrażeń i przemyśleń uzyskanych właśnie dzięki szerszej perspektywie. Przemyśleń tak wnikliwych, że nie zawsze dobrze poddających się werbalizacji, także ze względu na dostępną aparaturę pojęciową. Pół wieku później wydaje się, że w jednym przynajmniej aspekcie - „potencjalnej faktyczności” jesteśmy już w zupełnie w innym miejscu, ponieważ pozyskaliśmy ważny zestaw narzędzi teoretycznych. Możemy więc śmiało podjąć próbę przeformułowania myśli Schönego współczesnym nam językiem.

Skoro Albrecht Schöne opublikował Emblematik und Drama w 1964 - było to ledwie dwa lata po ogłoszeniu How to Do Things with Words Johna Austina. Trudno przypuścić, aby znał to dzieło odległej dyscypliny. Z całą pewnością natomiast nie mógł znać całej później rozwiniętej, wywodzącej się z przemyśleń Austina i przeobfitej teorii performatywów. Tymczasem dzisiaj kluczowe i zarazem najbardziej sporne twierdzenie Schönego, że emblemat „ustanawia pewną potencjalną faktyczność", od razu kieruje rozważania w tę właśnie dziedzinę. „Emblemat jest odmianą performatywu”- mówi dziś nam Schöne. Skoro zaś tak - każe szukać wokół emblematu i w powiązaniu z nim procesów, które moglibyśmy określić jako performanse.

\section{EMBLEMAT I PERFORMANS W REFLEKSJI DZISIEJSZEJ}

Nie trzeba szukać długo. Refleksja nad procesualnym charakterem emblematu - refleksja, w jakiej mierze emblemat generuje, prowokuje, katalizuje i podsumowuje pewne ciągi ludzkich zachowan - towarzyszy nowoczesnym badaniom tej dziedziny od ich zarania. Już Heckscher i Wirth widzieli w emblemacie zagadkę: jak powiązać inscriptio z pictura? Subscriptio służyłoby w tym układzie za podpowiedź ${ }^{29}$. Schöne falsyfikuje podobną interpretację najstarszym wśród badaczy emblematów sposobem: wskazuje wiele niezgodnych z nią przykładów u samego Alciatiego ${ }^{30}$. Także u niego jednak współgra trzech elementów w emblemacie ma naprowadzać na pewną tajemnicę: prześwitującą rzeczywistość, zagadkową prawdę. Tyle że nie jest to zagadka $\mathrm{z}$ ustalonym rozwiązaniem; jest to raczej problem fundamentalny, którego ostateczne rozwiązanie nikomu $\mathrm{z}$ nas nie jest wiadome.

29 „W przypadku emblematu mamy zatem do czynienia z zespoleniem słów lemmy i obrazu ikonu w zagadkę, której rozwiązanie możliwe jest poprzez epigram", W. S. Heckscher, K. A. Wirth, op. cit., sekcja I c.

30 A. Schöne, op. cit., s. 19-20. 
Trzeba bowiem wyraźnie zaznaczyć, że prawda, której służy emblemat, jest prawdą enigmatyczną, nieuchwytną. Rzeczywistość, którą w trybie performatywnej potencjalności emblemat ustanawia, nie daje się w pełni wysłowić ani też w pełni przedstawić. Stąd konieczność zderzania ze sobą słów i przedstawień, obrazów i działań, nazw i opisów, czyli różnych kategorii mimesis po to, by - parafrazując Simone Weil - ująć w nie prawdę jak w szczypczyki. Daly podkreśla, że co do tego akurat badacze emblematów wydają się zgodni:

Sądzę, że intencją autorów emblematów było oddanie tego, co uważali za prawdę, prawdę o charakterze moralnym lub religijnym, nie zaś jakiejś cząstki wiedzy. Twórca emblematu posługuje się wiedzą, aby przekazać tę szerszą prawdę ${ }^{31}$.

Przeciwstawienie prawdy i wiedzy: prawdy rozumianej ontologicznie jako to, co j e s t, i wiedzy, rozumianej jako zespół mniemań, którymi posiłkujemy się, by pojąć z prawdy jak najwięcej. Przekonanie, że prawda zawsze jest większa i szersza od jakiejkolwiek naszej wiedzy o niej, wydaje się dla emblematu konstytutywne.

„Czy emblemat jest produktem, czy procesem?”32 - pyta też w czterdzieści lat po Schönem Daly i opowiada się raczej za pierwszym z tych rozstrzygnięć. Jego zdaniem stanowisko przeciwne:

zakłada pewien akt wiary, skoro dzisiejsi badacze mają przyjąć, że emblemat reprezentuje „proces czytelniczy", pomagający czytelnikom odgrywać coraz to bardziej aktywną i niezależną rolę w produkcji sensów.

Daly kończy więc retorycznym pytaniem: „Gdzież są świadectwa odzewu czytelniczego?" 33 - choć przecież sam je gromadzi. Tysiące tytułów, miliony egzemplarzy, na które niejednokrotnie się powołuje, dają aż nadto wymowne świadectwo odzewu czytelniczego. Do tego dochodzą niezliczone i z równym zapałem tropione echa ksiąg emblematycznych w różnych dziedzinach kultury. „Produkcja sensów", wedle powszechnego konsensusu, miała stanowić główny użytek emblematów - czego tu jeszcze trzeba?

Właśnie w kontekście procesu rozpatruje emblemat Frances Yates. Emblemat to dla niej rekwizyt mnemoniczny, służący procesowi zapamiętywania, a przezeń - wywodom retorycznym, publicznym agonom, naukowym i religijnym dysputom: licznym i wielorakim procesom zachodzącym między ludźmi ${ }^{34}$. Mario Praz zaś zwraca uwagę, że stanowiąca szczególny przypadek emblematu impresa,

31 P. M. Daly, The Emblem..., op. cit., s. 83.

32 Ibidem, s. 16.

33 Ibidem.

34 „Najbardziej charakterystyczne dla Renesansu formy wyobrażeniowe to emblematy i imprese. Zjawiska te, choć nigdy nie traktowano ich z punktu widzenia mnemoniki, do niej właśnie należą", F. A. Yates, Sztuka pamięci, przeł. W. Radwański, Warszawa 1977, s. 131. 
jest niczym innym, jak symboliczną reprezentacją celu, życzenia, sposobu postępowania (impresa jest tym, co zamierza się imprendere, czyli przedsięwziąć) poprzez motto i obraz, które wzajemnie się interpretują ${ }^{35}$.

Jest ona - jak thumaczy chwilę później, referując poglądy Torquata Tassa - „nie tyle działaniem, ile wyrażoną myślą czy zamiarem, by je podjąć" ${ }^{36}$. To sformułowanie wprost już odsyła nas do myśli Richarda Baumana, który za performans uważa właśnie czynność powiązaną z jej zamiarem, modelem czy wzorcem ${ }^{37}$. Emblemat byłby czymś $z$ tej grupy - nieodzownie ewokującym działanie i służącym mu za punkt odniesienia. I podczas gdy emblemat - zdaniem Tassa - „zakłada trudności”38, performans - zdaniem Jona McKenziego - zawsze pojawia się w odpowiedzi na wyzwanie ${ }^{39}$, aby związane z nim trudności pokonać.

\section{EMBLEMAT JAKO ZARZEWIE PERFORMANSU U HARSDÖRFFERA}

Jak widać na przykładzie Tassa, świadectw ściśle lokujących emblematy w obrębie jakiegoś procesu - ludzkich zachowań, rozumowań czy kategoryzacji - możemy szukać nie tylko u dzisiejszych badaczy, ale i u autorytetów dawnej epoki. Wśród nich bodaj najpoważniejszy jest niemiecki pisarz, myśliciel i aktywista Georg Philipp Harsdörffer: do niego odwoływali się wszyscy cytowani tu uczeni. Jego życie w większości przypadło na czasy wojny trzydziestoletniej, poświęcił je pielęgnowaniu rodzimej kultury w czasie katastrofy i tuż po niej. Najtrwalszy bodaj, choć niepodpisany pomnik jego działalności zachowuje do dziś sam język niemiecki, albowiem Harsdörffer, oczyszczając ojczystą mowę z makaronizmów, tworzył wyrazy, które przyjęły się i funkcjonują potocznie do dzisiaj: Aufzug czy beobachten. Spośród zaś licznych dzieł tego autora głównym stały się wydane w sześciu tomach (raczej: tomikach) Frauenzimmer Gesprächspiele.

W założeniu nawiązywały one do Erazmiańskich Colloquia familiaria, dlatego Szyrocki tłumaczy tytuł jako Rozmówki białogłowskie. Jednak tłumaczenie to gubi ważny dla zrozumienia całości człon: spiele. Ściślejszym przekładem tytułu byłyby więc może Białogłowskie gry mowne czy też po prostu Zabawy mowne, jako że ochronną „,białogłowskość” dzieło traci już po dwóch tomach; odtąd widomie ma służyć ogólniejszemu pożytkowi.

35 M. Praz, Studies..., op. cit., s. 58.

36 Ibidem, s. 59.

37 R. Bauman, Folklore, Cultural Performances, and Popular Entertainments: A Communications-Centered Handbook, New York 1992, s. 41. Por. M. Carlson, Performans, przeł. E. Kubikowska, Warszawa 2007, s. 29.

38 M. Praz, Studies..., op. cit., s. 59.

39 J. McKenzie, Performuj albo..., przeł. T. Kubikowski, Kraków 2011, s. 3 i nast. 
Jedną z wcześnie - już w pierwszym tomie - proponowanych przez Harsdörffera „zabaw mownych” jest właśnie gra w emblematy:

Można [...] z emblematów (Sinnbilden [!]) wywieść zabawy mowne [...], jako to:

I. Że się coś zadaje, aby wynaleźć do tego emblemat.

II. Że się wybiera obraz i wspólnie szuka dla niego nagłówka (Obschrift).

III. Że się tworzy nagłówek i wynajduje do niego obraz lub figurę.

IV. Że się obrazuje cały ustęp z Pisma Świętego.

V. Kiedy się wszystkie żywioły przebywa i wyprowadza z nich emblematy, jako to Camerarius i Aldrovandus uczynili poprzez opisanie zwierząt, albo też ze wszystkiego, co widoczne, czyni się jeden lub więcej emblematów.

VI. Kiedy się od poety bierze wszystko, co zdatne, na nagłówki emblematów ${ }^{40}$.

Nawet w tym krótkim fragmencie Harsdörffer daje upust swojej pasji zniemczania słów obcych. W miejsce greckiego „emblematu” ukuł rodzime słowo Sinnbild $^{41}$, a łacińskie inscriptio to dla niego Obschrift.

Trzy pierwsze punkty jego dyspozycji projektują proces emblematyczny właśnie jako ludzką, międzyludzką grę w produkcję sensów. Pierwszym jej zalążkiem (punkt I) jest przedmiot emblematu: „coś”, co okazuje się nieuchwytne i niewyrażalne do tego stopnia, że trzeba co najmniej paru różnych systemów kategorialnych, by owo Coś - ową Osobliwość - w nie ująć. Oto enigma, którą w emblemacie dostrzegają również współcześni nam teoretycy. Proces-grę można jednak inicjować też inaczej, poprzez proste wyzwanie międzykategorialnego przekładu (punkty II-III) jakoś już w jednym medium określonej treści. Tutaj także, oczywiście, w domyśle pojawia się owo „coś” z punktu I - jako wspólny desygnat stworzonego $\mathrm{w}$ emblematycznej grze słowno-naocznego zespołu. Być może też owo „coś” napotyka się czy odnajduje dopiero w trakcie zabawy. Jej zasadą mogą przecież być łącznie punkty I i II albo też I i III - ożywczych kombinacji i niuansów może u źródła procesu zaistnieć wiele.

Jeśli punkty I-III określają procedurę, to punkty IV-VI ciekawie i precyzyjnie wskazują strefy, gdzie szuka się podstawowej dla emblematu Osobliwości. Punkt IV mówi o sferze transcendentnej, dokąd sięgamy poprzez Pismo Święte. Tam

40 G. P. Harsdörffer, Frauenzimmer Gesprechspiele, so bey Ehr- und Tugendliebenden Gesellschaften, mit nutzlicher Ergetzlichkeit, beliebet und geübet werden mögen: Aus Italiänischen, Frantzösischen und Spanischen Scribenten angewiesen, t. 1, Nürnberg 1644, s. 50-51, http://diglib.hab.de/ drucke/lo-2622-1/start.htm [dostęp: 16 IV 2020].

${ }^{41}$ Nie spostrzegł tego świetny skądinąd polski thumacz innego fundamentalnego dzieła o niemieckim teatrze barokowym, na którym oparł się w wielu miejscach Schöne. W Źródle dramatu żałobnego w Niemczech Benjamina Harsdörfferowe słówko Sinnbilder Kopacki przekłada za pomocą eufemizmu - jako „obrazy posiadające sens” lub podobnie - zamiast wprost jako „emblematy”. Czasami te nieuzasadnione omowności zaćmiewają sens wywodu Benjamina. Por. np. W. Benjamin, Źródło dramatu żałobnego w Niemczech, przeł. A. Kopacki, Warszawa 2013, s. 247; także: ,ilustracja sensu” - ibidem, s. 314. 
udawał się choćby Zbigniew Morsztyn, którego Emblemata za motto biorą wersety z Pisma, opatrując je stosowną subskrypcją (to emblemata nuda, oczywiście). $\mathrm{W}$ punkcie $\mathrm{V}$ mamy jako źródło emblematu naocznie postrzeganą, zmysłowo doświadczaną przyrodę. W punkcie VI - ludzkie wnętrze, nieuchwytnie wyrażające się $\mathrm{w}$ poezji4 ${ }^{42}$; przestrzenie ludzkiej psychiki lub fantazji.

Transcendencja - natura - jaźń. Trzy zasadnicze sfery tego, co niewyrażalne, nieprzedstawialne, niewysławialne. Sfery, z którymi mierzy się i nigdy nie może się uporać ludzka jednostkowa, kategoryzująca świadomość. Zabawa, którą proponuje Harsdörffer, pomaga zrozumieć, dlaczego w XVI i XVII wieku emblemat stał się ludziom tak bardzo potrzebny.

\section{EMBLEMAT A PERFORMANS: BLIŻSZE ZWIĄZKI}

W tym momencie należałoby znów pochylić się nad pytaniem Daly'ego: „produkt czy proces?" Czy to jest dobrze postawione pytanie? Czy rzeczywiście mamy tu do czynienia $z$ alternatywą? Czy nie jest tak, że emblemat w swej materialnej postaci stanowi rekwizyt, a zarazem instrukcję pewnego procesu, przez który sam się thumaczy i uzasadnia? Skoro emblemat daje nam zestaw rozłącznych elementów, które należy zderzyć ze sobą we własnej świadomości czy pamięci albo w komunikacji z innymi - czy nie mamy tu do czynienia z nierozerwalnym sprzężeniem? Przy wszystkich niedostatkach takiej analogii: czy produkt, jakim jest talia kart, można sensownie i ściśle rozpatrywać w oddzieleniu od procesu, któremu służy? I na odwrót ${ }^{43}$ ?

Schöne w przywoływanym już zdaniu zdefiniował proces emblematyczny jako proces heurystyczny: „każdy emblemat przyczynia się do wyjaśnienia, wytłumaczenia i wykładni rzeczywistości”. W tym właśnie procesie obrazowi czy akcji dramatycznej przysługiwać ma pierwszeństwo, jako że według Schönego znajdują się one bliżej rzeczywistości „surowej”, nieskategoryzowanej. Można rozumieć, że niejako pośredniczą pomiędzy tą rzeczywistością a bardziej wyabstrahowanymi elementami emblematu, więcej nawet: że ją wobec tych elementów jakoś reprezentują. Stąd chyba osobliwa, wielokrotnie dyskutowana i nie do końca jasna kolejna teza Schönego; czwarty filar jego koncepcji, o którym dotąd nie było mowy. Otóż emblematycznej res picta przysługuje zarówno byt, jak i znaczenie (Sein und Bedeutung); wszystko, co przedstawione w ikonie, zarówno

42 Oczywiście poezja może dotyczyć którejś z pozostałych dwóch sfer (lub czegokolwiek innego), jednak zawsze zostaje to zapośredniczone przez osobowość poety czy poetki i ich z kolei subiektywność.

43 Zresztą przecież i taliom kart nieustannie przydaje się różnorakie emblematyczne wymiary począwszy od arkanów tarota, a skończywszy na poczciwych: „czarnej Mańce” i „dupku żołędnym”. 
tworzy konkretną, naocznie postrzeganą scenę (Fredrowska skrzydlata stopa... na żółwiu wśród kwiatków...), jak i odsyła do dalszego „czegoś”, czyli do transcendentalnej wobec całego emblematu Osobliwości. Ten niejasny, migotliwy status, mający zapewne objąć symboliczny i alegoryczny wymiar pictura, najłatwiej chyba zrozumieć przez podobieństwo snu.

Trudno natomiast, nawet przy dwojakim rozumieniu pictura, zaaprobować dziś Schönowską hierarchię pierwszeństw. Wydaje się, że na jego myśli mocno zaciążyły przeświadczenia zmierzchającej właśnie epoki. Kołacze się w niej bowiem jeszcze Roussowskie przekonanie o wtórności i fałszu pisma wobec bardziej spontanicznych reprezentacji: przekonanie, że myśl w duszy leci bystro, nim się w słowach - zwłaszcza pisanych - złamie. Tymczasem jego książka ledwie o trzy lata poprzedza $O$ gramatologii Derridy; prezentowany przez Schönego porządek podskórnych przeświadczeń już wkrótce miał zacząć się kruszyć. Z dzisiejszej perspektywy nie warto próbować ściśle hierarchicznej strukturyzacji emblematu; zwłaszcza wedle zasady ,pierwotności” składników.

Skoro staramy się zachować z myśli Schönego jak najwięcej, lepiej chyba na koniec przyjąć, że emblemat pomaga uchwycić jakiś element rzeczywistości - rzeczywistości potencjalnie faktycznej - zderzając ze sobą rozmaite porządki kategorialne, różnorako wyrażające się w języku, działaniu i obrazie (a może i w dźwięku czy zapachu?), różnie też ze sobą wstępnie posplatane i nawet w sobie nawzajem pozagnieżdżane. Zarówno dobór tych porządków, jak i przebieg samego zderzenia wykazuje niezliczone wręcz bogactwo odmian, kombinacji i wariantów (co skutecznie utrudnia ścisłą i pozbawioną elementów arbitralnych definicję emblematu).

Emblemat można więc ująć jako kuźnię kategorialną, w której kształtuje się i przekształca nasze rozumienie rzeczywistości w jej wszystkich potencjach; proces emblematyczny jest właśnie dynamicznym procesem rozpoznawania rzeczywistości aktualnej i rzeczywistości potencjalnych. Takie rozumienie emblematu zgadza się zaś z wychodzącym od przypomnianej tu już definicji Richarda Baumana pojęciem performansu, które zaproponowałem niegdyś w książce Reguła Nibelung $a^{44}$ i które rozwinąłem $\mathrm{w}$ kilku następnych moich pracach. $\mathrm{O}$ ile performans w najszerszym rozumieniu byłby czynnym rozpoznawaniem rzeczywistości, czynnym kategoryzowaniem jej i jej potencjalnych wariantów oraz praktycznym lokowaniem w niej performującego podmiotu, o tyle emblemat mógłby w performansie uczestniczyć: prowokując do niego, stymulując go czy też służąc za notatkę z jakiegoś jego etapu. Mógłby służyć za pomoc w ludzkim powszednim performansie w wymiarze zarówno jednostkowym, jak i - zwłaszcza - społecznym. To tłumaczyłoby jego popularność.

44 T. Kubikowski, Reguła Nibelunga. Teatr w świetle nowych badań świadomości, Warszawa 2004. 
Jeśli przyjmiemy, że performans rozgrywa się zawsze na granicy świadomości i tego, czego ona nie obejmuje - to działa na tej granicy i emblemat. Jego uświadomione, skategoryzowane już w słowie, obrazie czy zachowaniu elementy wskazują bowiem na pozaświadomą Osobliwość, do której chcemy dotrzeć, a której pojąć i ująć (jeszcze) nie umiemy. Jeżeli zaś przyjmiemy, że teatr w swych najprzeróżniejszych formach także pomaga $\mathrm{w}$ powszednim ludzkim performansie, właśnie ludzkie performanse obierając sobie za Osobliwośćc ${ }^{45}$, to powstałe już analogie pomagają zrozumieć wiele kolejnych. Na przykład tę: i teatr, i emblemat przybierają tak niewyczerpaną mnogość różnych historycznych form, że nie da się zebrać ich cech kanonicznych, by złożyć je w definicję, której by nie podważano i nie oskarżano o apodyktyczność. Analogie te wyjaśniają wreszcie wspólne obu sztukom marzenia o Gesamtkunstwerk, od których zaczęliśmy. Skoro bowiem i w teatrze, i przez emblemat gromadzi się i zestraja różne procesy i porządki kategoryzacyjne, w harmonii albo wielorakich dysonansach i kontrapunktach zderzając je z nieogarnioną, wiecznie się wymykającą rzeczywistością natury, nas samych czy transcendencji - to nie dziwi dążenie, by ów proces intensyfikować, by wzmagać pogoń za rzeczywistością, uaktywniając tych porządków coraz więcej, włączając ich w pogoń coraz więcej, aż w końcu w marzeniu puści się w ruch wszystkie, do jakich człowiek jest zdolny.

\section{EMBLEMATYCZNY CHARAKTER SCENARIUSZY TEATRALNYCH I DOKUMENTACJI TEATRALNEJ}

„Naturo, tyś mi bóstwem” („Thou, Nature, art my goddess”) - oświadcza w Królu Learze Edmund, kiedy tylko zjawia się na scenie. „Słuchaj, naturo, ukochane bóstwo" („Nature, hear, dear goddess”) - wtóruje mu Lear ledwie dwie sceny później. Jednak według Edmunda owo bóstwo wspiera tryumf silniejszego, sprytniejszego i bardziej bezwzględnego, każe mu bez skrupułów rozprawić się z niedołężniejącym ojcem i niezaradnym bratem. Według Leara natomiast, natura każe dzieciom opiekować się rodzicami, a nawet podporządkować się ich starczym despotyzmom. Natura - sfera płynnej anomii i indywidualnej walki o byt silniejszego. Natura - sfera niewzruszonych hierarchicznych reguł i solidarności między pokoleniami. Ten konflikt, jeden z podstawowych w Królu Learze, jest jasny, wprost deklarowany i dobrze znany.

Spójrzmy nań jednak z bliskiej nam teraz formalnej strony. Czy to, co mówią i Edmund, i Lear, nie stanowi ich własnych, osobistych, wykluczających się wzajem subskrypcji pod nieuchwytnym dla nich obydwu pojęciem ,natury”? Natury,

45 Por. idem, Przeżyć na scenie, Warszawa 2015. 
która każe nam starzeć się i umierać, łączy nas więzami rodowodowymi, różnie rozdziela zdolności, sprawności i wrażliwości? Niepojętej i przemożnej? To przecież ta sama natura, w której tematów dla Sinnbilder nakazał szukać Harsdörffer. To sfera Osobliwości, której nie zdołają wypełnić nawet najgęstsze sploty subskrypcji, ikon i lemm. Wiecznie niepokojący konflikt Leara i Edmunda czy raczej opisany właśnie aspekt ich wielostronnego i wielopiętrowego konfliktu stanowi jedno z nieskończenie wielu zagadnień, które z dziedziny natury można wywieść. I można wokół niego budować zarówno emblemat, jak i akcję dramatyczną.

Jeżeli teraz w ślad za Schönem uznamy akcję dramatyczną za pełnoprawną pictura, czy nie może nas to poprowadzić do śmiałego podejrzenia, że scenariusz dramatyczny/dramat - przybiera strukturę emblematu? Król Lear to jedynie wyrazisty, dobrze znany przykład, ale kwestia jest bardziej generalna: czy dramat taki, jakim go znamy, traktowany jako zalążek/instrukcja akcji dramatycznej, nie wykazuje struktury emblematu? Emblematu, powtórzmy, w którym akcja zajmuje miejsce pictura, a zderzają się z nią i wzajem ze sobą wszystkie kwestie tekstowe, przeplatające się $\mathrm{w}$ zamiennych, niedookreślonych i nawet niekoniecznie każących się dokładnie określić rolach in- i subskrypcji? Wtedy całość dramatu - jeśli dobrze wykonana - intryguje, prowokuje, by rozwiązywać ją już nawet nie poprzez Gespräch- lecz przez Aktionspiel: spróbować ją rozwiązać poprzez sceniczne jej odegranie.

Emblemat byłby więc naprawdę zalążkiem performansu, w tym performansu teatralnego? Jego instrukcją? Spójrzmy teraz od drugiej strony: co zostaje po przedstawieniu teatralnym? Żywa pamięć, oczywiście, która porusza, inspiruje - ale też z czasem blednie, chce się więc ją zatrzymać i przekazać innym. W obydwu tych przypadkach, w upływie czasu i w komunikacji - żywe, umykające wspomnienie samo staje się Osobliwością, którą utrwalić, wyrazić, przekazać trudno. Im później, im dalej, tym trudniej.

Oczywiście służą temu dokumenty, jeszcze przez Stefanię Skwarczyńską nazwane dokumentami dzieła. Dokumenty ikonograficzne - odręczne szkice, fotografie, zapisy wideo i audio - pozwalają w części utrwalić naoczność (w przypadku zapisów audio: nauszność?). Schöne zapewne uznałby, że są najbliższe Osobliwości samego teatralnego zdarzenia, że dają jej rozmaite picturae. Istnieją też dokumenty tekstowe. Czy nie jest tak, że krytycy, zdający innym sprawę z widzianego przedstawienia i próbujący jego opisu, oraz widzowie, notujący na własny lub cudzy użytek wrażenia i refleksje, przydają nieuchwytnemu minionemu zdarzeniu własne subskrypcje?

U źródeł przedstawienia teatralnego - poza żywą pamięcią i świadomością jego twórców - leży więc wielogłosowy tekst dramatu lub szereg tekstów zbieranych i montowanych przez dramaturga; leżą też jakieś inspirujące twórców lub przez nich tworzone ikony, picturae statyczne lub ruchome. Kiedy zaś przedstawienie 
się odbędzie i kiedy gaśnie jego żywa pamięć, zostają po nim stałe lub ruchome obrazy i zbiór tekstów. Na początku i na końcu procesu performatywnego mamy więc zestaw emblematyczny. $Z$ początku służy on temu procesowi - mówiąc metaforycznie - za suchy zaczyn lub za rozpałkę. Na końcu jest zaś jedynym, co po procesie materialnie pozostało. Jest też jedynym pozostałym, jedynym ostatecznie możliwym medium jego społecznego przekazu.

Im proces odleglejszy, tym bardziej staje się to widoczne. Dziś żyją jeszcze ludzie, którzy widzieli Księcia niezłomnego Jerzego Grotowskiego ${ }^{46}$. Jednak już przecież dla zdecydowanej większości zainteresowanych przedstawienie to realnie polega na szeregu ikonicznych fotografii Ryszarda Cieślaka. Polega na znieruchomiałych na zawsze w picturae pasyjnych, barokowych układach jego uchwyconego w ruchu, odzianego w perizonium ciała; oraz na wielkiej, wciąż mnożącej się obfitości tekstów i komentarzy do tych tekstów, i komentarzy do komentarzy, i wreszcie syntez wszystkich uprzednich tekstów: na bujnym gronie subskrypcji coraz dalszego rzędu. Nie zmienia tej sytuacji fakt, że po dziesiątkach lat od premiery i wygaśnięcia spektaklu jego ustabilizowaną i - zdawałoby się - ustaloną już emblematykę wzbogacił zrekonstruowany i udostępniony zapis wideo. Owszem, ma on wartość jako kolejna ikona, cechująca się może jeszcze wyższym ideelle Priorität od dotąd poznanych - ale to wszystko.

Przykład Księcia niezłomnego jest o tyle wyrazisty, że mamy tu do czynienia $\mathrm{z}$ teatrem, który z założenia stronił od werbalizacji i ikonizacji, i który w pracy swej kładł nacisk na to, co pozakategorialne. Zdaje się, że nawet on nie zdołał uniknać ostatecznej emblematyzacji. Zupełnie innym przykładem utrwalonej w emblematach międzyludzkiej efemerydy może być z kolei dzieło, które stało się nagłym, potężnym i ważkim historycznie faktem społecznym za cenę szybkiego unicestwienia - Dziady Kazimierza Dejmka ${ }^{47}$. Tutaj zestaw zwykłych pisemnych subskrypcji wygląda nieco inaczej. Tekstów stricte krytycznych - na czele z najszczegółowszymi Zbigniewa Raszewskiego - z przyczyn cenzuralnych jest bardzo niewiele; dochodzi do nich natomiast ważny zbiór dokumentów życia społecznego. Prócz tego - ikoniczny zestaw fotografii, parę fragmentów filmowych i znów po pół wieku opracowany zapis dźwiękowy premiery. Wszystko razem tworzy zespół emblematyczny, poprzez który dochodzić można i kształtu teatralnego dzieła, i zwłaszcza tego, co działo się przy jego prezentacjach: premierowego wieczoru 25 listopada 1967 i na ostatnim otwartym dla widzów przedstawieniu 30 stycznia 1968.

46 Książę Niezłomny do słów Calderona-Słowackiego, scenariusz i reż. J. Grotowski, architektura J. Gurawski, prem. wariantu I 25 IV 1965 w Teatrze Laboratorium 13 Rzędów we Wrocławiu.

47 Dziady Mickiewicza, układ tekstu i reż. K. Dejmek, prem. 25 XI 1967 w Teatrze Narodowym w Warszawie. 
Dramat takich właśnie przejść - od żywego wydarzenia, żywego procesu, żywego wspomnienia do suchej sterty ikonicznych i tekstowych przekazów ukazywał na przykładzie dziedzictwa Grotowskiego spektakl Poor Theater The Wooster Group ${ }^{48}$, przedstawienie borykające się z niemożliwością wskrzeszenia oryginalnego przebiegu (w tym wypadku: spektaklu Akropolis) z jego emblematycznych pozostałości (na czele z rejestracją telewizyjną). Za smutną konkluzję spektaklu mogły służyć słowa Elizabeth LeCompte - fragment wspomnienia z wizyty po wielu latach w przebudowanej już wrocławskiej sali Apocalypsis - że po miejscu jej młodzieńczych uniesień pozostała tylko podłoga, oryginalny parkiet, którego dotyk pozwolił LeCompte odnaleźć łączność z dawnym doświadczeniem. Choć lepiej to samo powiedzieć inaczej. Słowa LeCompte niekoniecznie były konkluzją przedstawienia. Są raczej lemmą emblematu, który wychynął z pamięci jednego z niegdysiejszych widzów tego od dawna już niegranego spektaklu. I właśnie ten emblemat ów widz - autor tego tekstu - w tej chwili i w tej postaci przekazuje.

Ksiaże niezłomny, Dziady, Poor Theater - to spektakle, których widzowie i nawet niektórzy aktorzy wciąż żyją. Ich emblematy nie skrystalizowały się jeszcze do końca; w żywej pamięci pozostaje wciąż coś poza nimi. W dalszej jednak perspektywie - dzielącej nas od przedstawień Reduty, Wyspiańskiego, Bogusławskiego, Shakespeare'a i Ajschylosa - emblematyczny charakter teatralnych pozostałości staje się jaskrawo wyraźny. Nie pozostaje nic więcej.

Sztuka emblematu powstała i rozkwitła w czasach, gdy tworzyły się także podstawowe formy nowożytnego teatru. Kwitła wtedy też - od Giulia Camilla po Francisa Bacona - teatralna metafora obejmująca coraz to nowe sfery ludzkiego życia i poznania. W istocie - jak najbardziej chyba przekonywająco pokazała Julie Stone Peters - na wielką skalę dokonywała się wówczas „reinwencja teatru”. Podjęto masowy wysiłek, aby dorozumieć się i praktycznie wypróbować, na czym mogła polegać owa instytucja starożytnych kultur. Ta „reinwencja” dokonywała się w niewielkiej tylko części na podstawie żywych gatunków widowiskowych. W większości sięgano do pozostałości tajemniczego „teatru” dawnych kultur: do zachowanych tekstów i obrazów składających się w zestaw emblematyczny ${ }^{49}$. Po czym, jak pisze autorka:

Ci, którzy uważali się za obeznanych w nowoczesnej estetyce, zaczęli czuć, że drukowany dialog, głośno czytany przez sąsiadów, nie był prawdziwym dramatem, że pokazy zwierzęce

48 POOR THEATER - a series of simulacra, The Wooster Group, reż. E. LeCompte, prem. 19 XI 2003 w The Performing Garage w Nowym Jorku. Pokazy w Teatrze Dramatycznym m. st. Warszawy 16-20 XI 2004.

49 Por. J. Stone Peters, Theatre of the Book 1480-1880. Print, Text and Performance in Europe, New York 2003, zwłaszcza s. 93-129. 
i popisy gimnastyczne ze śpiewkami nie stanowiły przedstawień teatralnych w ścisłym sensie, ale że teatr polega na aktorach, którzy w przestrzeni sceny ze swoistymi parafernaliami performują swoiste teksty ${ }^{50}$.

I trochę dalej podsumowuje ów niezwykły moment kulturowego zapłonu:

Teatr stał się dla renesansu tak kluczową metaforą nie tylko ze względu na to, że instytucjonalnie stał się centrum opowiadania historii i odzwierciedlania kultury, lecz ze względu na jego rolę we wiązaniu ze sobą mowy i pisma, performansu i książki ${ }^{51}$.

Tę samą rolę odgrywał przecież emblemat. Trzeba zatem przynajmniej postawić pytanie: czy tak wspaniała równoczesna kariera teatru i emblematu, ostentacyjnie wplecionych w główny nurt gwałtownego ożywienia kulturowego, czyli w nurt intensywnego cywilizacyjnego performansu wobec wielorakich wyzwań - nie stanowi kolejnej poszlaki, że sztuki te łączy więź? Skoro - jak widać z przytoczonego tekstu Peters - role teatru i emblematu w ówczesnej kulturze opisać można tymi samymi słowy: czy nie pełniły one jednej roli wspólnie? Czy procesy performatywne zachodzące $\mathrm{w}$ różnorakich theatrae - teatrach naprędce urządzanych na placach publicznych, przemyślnie budowanych według starożytnych wzorów, organizowanych przez magnatów w ich pałacach czy też wyobrażanych przez filozofów wewnątrz pałaców ich myśli - nie łączyły się ze sobą, nie komunikowały i nie oddziaływały na zewnątrz poprzez sieć różnorakich emblematów? Skoro by tak było, Schöne, opisując symbiozę teatru z emblematem w XVII wieku, nie uchwyciłby całego procesu: ledwie jego kulminację i schyłek.

Wracając teraz do głównego wątku: czy można zatem przyjąć, że ze spektaklu teatralnego na dłuższą metę pozostają emblematy i że tylko tymi emblematami możemy się dzielić w społecznym obiegu, możemy je przekształcać i wzbogacać? A także wykorzystać je do tworzenia następnych spektakli, skoro performatywny proces spektaklu teatralnego wychodzi od emblematycznego zaczynu? Czy nie jest więc w ogólności tak, że emblemat nieuchronnie towarzyszy procesowi performatywnemu jako jego produkt wyjściowy, uboczny, ostateczny lub wymarzony? Innymi słowy zaś: skoro performans uznajemy za „tygiel” i za „kuźnię kategorialną” - czy kategorie, stanowiące w owym tyglu materiał, w kuźni zaś wytwór i odpryski, nie zastygają właśnie w postać emblematyczną? Czy więc nie jest tak, że emblemat i performans to różne strony tego samego zjawiska, że wspólne roszczenia emblematu i teatru do budowy Gesamtkunstwerk nie oznaczają bynajmniej konkurencji, a trapiący Daly'ego dylemat: „produkt czy proces” wreszcie znalazł zadowalającą odpowiedź?

\footnotetext{
50 Ibidem, s. 104.
}

51 Ibidem, s. 106. 


\section{EMBLEMAT W SPOŁECZNYM OBIEGU PERFORMANSU}

Zasadnicze pytania trzeba poszerzyć o parę pomniejszych uwag i spostrzeżeń. Pierwsze jest oczywiście takie, że „teatr” nierównie bardziej jeszcze niż „emblemat” oznacza zbiór zjawisk proteuszowo zmiennych, diametralnie od siebie różnych, czasem kształtujących się w opozycji do siebie wzajem, przekornych wobec wszelkich prób ich pojęciowego określenia. Tworzy zbiór o wiele bardziej rozmyty niż ten, od którego zaczęliśmy. Trudno wręcz znaleźć na terenie teatru jakąkolwiek próbę teoretycznego uogólnienia, która nie byłaby natychmiast podważana jako arbitralne tworzenie lub sankcjonowanie „typu idealnego". Ucieczki od teatru, wyjścia z teatru, odejścia od niego - stanowią integralną część teatralnego pejzażu, zwłaszcza w epoce nowoczesnej. Nieodłącznym składnikiem dziejów teatru ostatniego stulecia jest jego samonegacja. To zrozumiałe: skoro uważamy teatr za performatywny tygiel do przetapiania wszelkich nadawanych światu kategorii, wówczas jasne jest, że w ogień idą także i kategorie ten tygiel definiujące. Czasami nawet należy przetopić je w pierwszej kolejności, żeby zyskać wiarygodność. Jednakże właśnie to powoduje, że składając wizytę w dziedzinie teorii emblematu, teoretyk teatru czuje się nieoczekiwanie swojsko. W mikroskali odnajduje tam znane aporie. Znajduje również bezradności, zacietrzewienia i zniechęcenia nieustannie wymykającym się przedmiotem rozważań, do jakich przywykł już na własnym gruncie. Paradoksalnie utwierdza to w poczuciu pokrewieństwa obydwu dziedzin: jest się w tej samej sferze musującej płynności.

Po drugie: emblemat podobnie jak teatr niewątpliwie jest zjawiskiem społecznym. Powstaje i spełnia się między ludźmi. Już na jego powstanie często składa się zbiorowy wysiłek. Harsdörffer czyni zeń grę towarzyską, jednak już założycielskie dla całego gatunku Emblemata Alciatiego powstały z tekstów tego autora i z ilustracji, które niezależnie dobrał im wydawca. Fakt zbiorowego autorstwa sprawia teoretykom emblematu kłopot, obcy chyba badaczom teatru, przyzwyczajonym do tego, że dzieło teatralne to przeważnie suma indywidualnych, nakładających się na siebie w czasie i przestrzeni wysiłków twórczych.

Co więcej: sukces emblematu jest też raczej sukcesem społecznym. Sztuka emblematu nie wydała arcydzieł. W imponującym zbiorze sześciu i pół tysiąca ksiąg nikt nie próbował dotąd ich wskazać, nie o to bowiem w tej sztuce chodziło. Jej wagę wyznacza skala oddziaływania: intensywność społecznej transmisji i skala odbioru czytelniczego. W epoce wczesnej nowożytności emblematy podlegały, jak już wiemy, niesłychanie intensywnej reprodukcji. Ich autorzy - jak elegancko ujął to jeden z badaczy - ,zapożyczali się wzajemnie, skoro tylko wysechł atrament”, powstałe zaś w ten sposób konstrukcje: „plagiował każdy w zasięgu wzroku: płatnerze, ludwisarze, krawcy, stolarze meblowi, jubilerzy, tkacze i tak 
dalej" 52 . W tych samych czasach obieg scenariuszy teatralnych, motywów dramatycznych i poszczególnych lazzi cechowała podobna swoboda i intensywnośćs3.

Po trzecie: $w$ intensywnym obiegu i nieprzebranej rozmaitości emblematy mogą spełniać najrozmaitsze funkcje. Podobnie jak w przypadku performansu: zarówno subwersywne, jak i normatywne. W emblematyczno-performatywnej grze kategorii tworzą się nowe ich zbitki, które przeciwstawiają się dawnym. Są ożywcze, atrakcyjne, wchodzą w szerszy społeczny obieg, po czym obracają się w loci communes i zastygają w kliszę czy banał, od którego następnie chce się uciec. Ale też emblematyczną grą kategorii można manipulować: narzucać jej rozwiązanie, traktować ją za Heckscherem jako zagadkę z ustalonym rozwiązaniem lub zaszyfrowaną instrukcję dla odbiorców. Skrajnie znormatywizowaną formę emblematyka przybrała chyba w postaci ikonologii: w książce Cesarego Ripy subskrypcja daje zawsze jednoznaczną, obowiązującą, jedynie słuszną interpretację eikonu $u^{54}$.

Czy nie jest wreszcie tak - po czwarte i ostatnie - że jeśliby prawdziwe było wysnute przez nas w poprzednim rozdziale podejrzenie, iż emblemat w swym nierozerwalnym zrośnięciu z performansem stanowi formę jego społecznego obiegu jako zdatny do szerokiego rozpowszechnienia ,suchy produkt” performansu, wówczas szczególnie podkreślałyby symbiozę z emblematem te odmiany teatru, które właśnie na szersze społeczne oddziaływanie się nastawiają?

\section{EMBLEMAT W TEATRZE POLITYCZNYM - TRADYCJA BRECHTOWSKA I AGITPROP}

Schöne kończy wykład uwagą, że emblematyczna konstrukcja, czyli akcja i podsumowujące ją subscriptio chóru, przeniosła się później w formę Singspiel. Marian Szyrocki, referując Schönego, formułuje trafne spostrzeżenie, że przecież można ją odnaleźć również w słowno-muzycznej konstrukcji dramatów Bertolta Brechta $^{55}$. Czy nie dałoby się tego spostrzeżenia rozszerzyć? Czy z naszego punktu widzenia Brecht nie uruchamia w swoim teatrze intensywnej, wielopłaszczyznowej gry emblematycznej, ,uobcowiając” wzajem wobec siebie rozmaite składające się na spektakl teatralny systemy kategorialne: tekst wypowiadany i pisany, akcję, muzykę, obraz? Różnorakie „wizerunki” [Abbildungen], na których tworzeniu polega jego zdaniem teatr? Sławny wyizolowany Gestus? Do swego teatru Brecht zaprasza przecież wszystkie heterogeniczne sztuki, ,a ich komuni-

52 R. J. Clements, Picta Poesis: Literary and Humanistic Theory in Renaissance Emblem Books, Roma 1960, s. 226.

53 Por. np. M. Surma-Gawłowska, Komedia dell'arte, Kraków 2015, s. 144-164.

54 Por. C. Ripa, Ikonologia, przeł. I. Kania, Kraków 1998.

55 Por. M. Szyrocki, op. cit., t. 1, s. 177. 
kowanie się ze sobą polega na tym, że sobie wzajemnie nadają piętno obcości" ${ }^{56}$. Teatr Brechta to wielki zderzacz emblematów, a zarazem wielki ich wytwórca. Niemy krzyk Matki Courage (z twarzą Heleny Weigel); sentencje wieńczące piosenki Opery za trzy grosze („Erst kommt das Fressen, dann kommt die Moral”); szekspirowsko-hitlerowska przemowa Artura Ui podporządkowującego sobie miasto (w polskim teatrze na zawsze już chyba połączona z figurą i głosem Tadeusza Łomnickiego) - zachowują bezpośrednią emblematyczną moc po dziś dzień.

W teatrze Brechta emblematyczny proces społeczny znalazł swój najsławniejszy generator. Łatwo jednak znaleźć jego precedensy u prekursorów dwudziestowiecznego teatru politycznego: w wielotworzywowej sztuce Piscatora, którą najlepiej może realizują z gruntu emblematyczne inscenizacje Hoppla, żyjemy! albo Przygód dobrego wojaka Szwejka ${ }^{57}$, czy wcześniej u Wsiewołoda Meyerholda. Czymże innym były wprowadzone przez Meyerholda dyskusje z publicznością po przedstawieniu, jeśli nie Harsdörfferową Gesprächspiel w jej punkcie drugim? Były przecież zbiorowym szukaniem nagłówka dla właśnie odbytej akcji; gromadzeniem w tym celu różnych subskrypcji; wspólnym ustalaniem emblematu, który ma pozostać po spektaklu.

Za realizację pierwszego punktu recepty Harsdörffera można z kolei uznać jeden z najgłośniejszych tworów powstałych w następstwie projektu Brechta: Teatr Forum Augusto Boala. Tam uczestnicy gry - „spektaktorzy” - obierają sobie za cel jakąś niewyobrażalną in concreto Osobliwość, którą stanowi „potencjalnie realne” rozwiązanie konfliktu czy napięcia społecznego. Następnie we wspólnej grze tworzą z akcji i słów emblemat ustanawiający taką właśnie rzeczywistość, dbając by nie kłóciła się z potocznymi realiami. Wytworzenie użytecznego społecznie i dynamicznego emblematu, który wspomoże codzienny performans „forumowiczów”, oraz zainicjowanie i moderowanie w „teatrze niewidzialnym” gry, która do powstania takich emblematów doprowadzi - oto podstawowy cel działań Boala.

Znane jest wydarzenie, które doprowadziło Boala do opracowania jego modelu teatru: to paradoksalna klęska performansu, w którym skutecznie udało mu się ze sceny narzucić publiczności normatywny emblemat, wywiedziony z dawnych wzorników teatru agitprop. Gdy zasiadający na widowni chłopi chcieli uczynić zeń punkt wyjścia kolejnego, pozascenicznego już performansu: przejęcia władzy w okręgu, Boal uświadomił sobie, że sceniczny emblematyczny wzorzec natychmiast krwawo pryśnie w zderzeniu z realnością; że performans, który wygeneruje, będzie katastrofą ${ }^{58}$.

56 B. Brecht, Małe organon dla teatru, przeł. A. Sowiński, „Pamiętnik Teatralny” 1955 z. 1, s. 62.

57 Por. E. Piscator, Teatr polityczny, przeł. R. Szydłowski, Warszawa 1983, s. 169-227.

58 Por. A. Boal, Without Symbols There Would Be No Civilisation, „European Journal of Arts Education" $1999 \mathrm{nr} 2$, s. 9-10. 
Agitprop, notabene, to sztandarowy przykład teatru zarazem skrajnie zemblematyzowanego - nieledwie stopionego w jedno ze swymi plakatami po to, by uzyskać przekaz społeczny szybko, dosadnie i skutecznie - i teatru bezwzględnie normatywnego. Związki emblematu $\mathrm{z}$ teatrem politycznym, $\mathrm{z}$ zaangażowanym teatrem społecznym niewątpliwie zasługują na wnikliwszą refleksję.

\section{EMBLEMAT W TEATRZE POSTMODERNISTYCZNYM I POSTDRAMATYCZNYM}

Emblematyzacja wydaje się też jedną z cech charakterystycznych formacji teatralnej, która na pierwszy plan wysunęła się przed czterdziestu laty i początkowo łączona z postmodernizmem lub nazywana „następną falą”, pod koniec XX wieku doczekała się popularnego miana „teatru postdramatycznego”. W opozycji do dominującego w latach siedemdziesiątych XX wieku nurtu, który nacisk kładł na bezkategorialną fazę procesu performatywnego (performer, zdaniem Grotowskiego: „rozporządza czynieniem, doing, a nie myślami albo teoriami”,59), formacja „postdramatyczna” położyła nacisk właśnie na fazę kategoryzacji, czyli fazę emblematyczną - jak ją tu chcemy nazywać. „Reżyser stosuje semiotykę” - głosi tytuł pierwszego rozdziału jednej z wczesnych ważnych prób scharakteryzowania tej formacji: Directing Postmodern Theater Jona Whitmore' ${ }^{60}$. I rzeczywiście, kwitnąca wówczas w dziedzinie teorii semiotyka teatru, rozmontowująca żywy spektakl na szereg odrębnych, a ściśle określonych i skodyfikowanych systemów kategorialnych, zarówno świetnie współgrała z tym akurat nurtem poszukiwań scenicznych, jak i mogła dawać mu inspirację i legitymizację.

Twórca pojęcia ,postdramatyzmu” Hans-Thies Lehmann wprost pisze o „teatrze heterogenicznym". Ten teatr czynnie walczy z syntezą przy jednoczesnej synestezji. „Samowystarczalna cielesność” aktorów - w której przedtem upatrywano ostoi bezkategorialności - teraz odarta z nimbu kulturowych legend, a za to opatrzona niewyczerpanym „potencjałem gestycznym”, staje się ledwie jednym z elementów wieloelementowego performance text. Co więcej - teatr „nieustannie przekracza granice bólu, aby przezwyciężyć rozdział ciała od języka"61! Cielesność może więc mieć tu najwyżej ten rodzaj „idealnego pierwszeństwa”, który przysługiwał pictura. Teatr lehmannowski jawi się w naszej perspektywie jako par excellence emblematyczny.

59 J. Grotowski, Teksty zebrane, red. A. Adamiecka-Sitek et al., Warszawa 2012, s. 812.

60 J. Whitmore, Directing Postmodern Theater: Shaping Signification in Performance, Ann Arbor 1994. Por. s. 1-30.

61 H. T. Lehmann, Teatr postdramatyczny, przeł. D. Sajewska i M. Sugiera, Kraków 2004, s. 149. Por. też strony poprzednie. 
Kiedy zaś oderwać się od książek i przez odpowiednie szkło spojrzeć na twórczość chociażby Roberta Wilsona, Piny Bausch, Franka Castorfa, Jana Lauwersa, Heinera Goebbelsa czy Romea Castellucciego - aby na chybił trafił wymienić kilkoro z najwybitniejszych jego przedstawicieli - wówczas teatr przełomu tysiącleci zaczyna jawić się oku jako wielopiętrowe i wieloskrzydłowe Emblematisches Gerüst nie mniej - choć rzecz jasna, zupełnie inaczej - niż Schönemu w ostatnim rozdziale książki objawił się europejski teatr XVII wieku' ${ }^{62}$. To także wymagałoby dokładniejszej obserwacji.

\section{MOC EMBLEMATYCZNA I PRZESTRZEŃ EMBLEMATYCZNA}

Wspomniane przy okazji Brechta określenie „emblematyczna moc” ujawnia nieodzowny aspekt stosunków teatru-performansu z emblematem. Aspekt o tyle delikatny, że wartościujący, a przez to - nie do końca uchwytny. Jeżeli, jak podejrzewamy, emblemat nieuchronnie sprzężony jest z performansem, to podobnie jak on może być fortunny albo niefortunny. I konsekwentnie można by przyjąć, że emblemat wtedy uznajemy za fortunny, kiedy jest w stanie wzbudzić proces performatywny; jest zaś niefortunny - kiedy tego uczynić nie zdoła. Skoro scenariusz spektaklu teatralnego (tradycyjnie, choć niekoniecznie mający postać dramatu) uznajemy za twór emblematyczny, fortunny jest on wtedy, kiedy da się na jego podstawie wygenerować żywy spektakl-performans. Emblemat zaś, który ostatecznie pozostaje w kulturze po tym spektaklu, fortunny jest wtedy, kiedy pobudzi i skatalizuje w niej dalsze procesy performatywne.

Kiedy tak się dzieje? Wstępnie przychodzi na myśl parę niezbędnych warunków. Po pierwsze: to, czego dotyczy emblemat, musi być rzeczywiście Osobliwością, nie zaś banałem. Emblemat powinien wskazywać aspekt rzeczywistości, który naprawdę ch ce s ię odkryć i dostrzec, lecz ciągle nie jest się w stanie tego osiągnąć w pełni. Emblemat ma wskazywać aspekt prawdy, który umyka ludzkiemu poznaniu. I musi on tę Osobliwość skutecznie i trwale utrzymać - by tak rzec - na celowniku.

Ażeby tak się stało, aby cel nie zsunął się z linii performatywnego strzału, trzeba umiejętnie dobrać składające się na emblemat systemy kategorii i różnokategorialne (heterogeniczne) przekazy. Muszą one być naprawdę do siebie niesprowadzalne. Napięcie między nimi nie może dać się rozwiązać. Napięcie pomiędzy subskrypcjami Leara i Edmunda wciąż trwa, kiedy zaś obydwie zderzyły się $\mathrm{z}$ ikoniczną akcją tragedii - i jeszcze mnóstwem innych, niewspomnianych tutaj

62 Osobne zagadnienie stanowiłyby tutaj widowiska, w których nie uczestniczą widomie aktorzy ani personifikacje i które polegają wyłącznie na transformacjach przestrzeni scenicznej, np. niegdysiejsze polskie przedstawienia Sceny Plastycznej KUL autorstwa Leszka Mądzika lub z nowszych przykładów - Stifters Dinge Heinera Goebbelsa. Czy z przedstawionego punktu widzenia można by je bez reszty traktować jako ruchome emblematy? 
subskrypcji, mott i lematów zawartych w tym samym tekście Shakespeare'a - powstał emblematyczny zaczyn, który od z górą czterystu lat nie przestaje frapować i skłania do generowania coraz to nowych performansów. Od czterystu lat też bezskutecznie usiłuje się n a z w a ć osobliwość, którą Król Lear ostatecznie miałby wskazywać; trwa wieczny, nierozstrzygalny konkurs na najlepsze inscriptio tej tragedii.

Zdolność otwarcia widza/czytelnika na ukryty za emblematem dalszy, nieuchwytny plan; zdolność, by skutecznie ożywić poczucie, że w tym nieuchwytnym planie coś naprawdę się znajduje - to zdolność, którą niezależnie od sporów o konstrukcję emblematycznych tworów przypisuje się emblematom jako konstytutywną. To właśnie poczucie kazało Diderotowi wykrzyknąć w sławnym passusie Lettre sur les sourds et muets, że ,wszelka poezja jest emblematyczna”i thumaczyć, że w dziele poetyckim słowo winno budzić zmysłowe wyobrażenia, a wprost wyrażana myśl powinna być przeniknięta „tkanką hieroglifów”, co nadaje całości l'esprit, ożywiający wszystkie zgłoski i poruszający duszę czytelnika ${ }^{63}$. Zdaniem Diderota kwalifikować coś jako poezję powinna owa transcendująca, ożywcza zdolność, którą uznaje się za swoisty przymiot emblematu.

„Tkanka hieroglifów”. Hieroglify - jak wówczas uważano - przedstawiają transcendencję $\mathrm{w}$ doczesnej postaci. Jeszcze raz zatem: emblemat jest fortunny, jest prawdziwym emblematem, jeżeli skutecznie otwiera ów plan nieuchwytny. Mogą go wskazywać symboliczne lub alegoryczne czy właśnie - po dawnemu - hieroglificzne własności pictura. Może on prześwitywać w szczelinach pomiędzy obrazem a tekstem albo między różnymi dyskursami złożonymi w emblematyczne rusztowanie. Każdy z tych elementów wyznacza jakiś wymiar czy biegun otwierającej się wielowymiarowej, wielobiegunowej przestrzeni. W tej przestrzeni swobodnie rozwija się performans, wykuwając, przetwarzając i wyrzucając z siebie nowe kategorie, które $z$ kolei będą mogły tę przestrzeń przeformować. Wypada nazwać ją przestrzenią emblematyczną; w niej zachodzi performans, performans ją wypełnia i tworzy.

\section{PRZESTRZEŃ EMBLEMATYCZNA W „TEATRZE ŻYCIA SPOŁECZNEGO"}

Pojęcie przestrzeni emblematycznej wprowadziłem w książce Zjadanie psów ${ }^{64}$, nie omawiając go tam bliżej; wydaje mi się ono jednak użytecznym narzędziem poznawczym. W książce tej zajmował mnie szczególny kulturowy per-

63 D. Diderot, Lettre sur les sourds et muets: à l'usage de ceux qui entendent \& qui parlent, b.m. 1751, s. 55-56. https://archive.org/details/lettresurlessou00didgoog/page/n67/mode/2up/search/emblematique [dostęp: 24 IV 2020].

64 T. Kubikowski, Zjadanie psów, Warszawa 2019. 
formans wypraw polarnych. W XIX wieku wywarł on wielki wpływ na świadomość współczesnych w całym niemal obrębie zachodniej cywilizacji i skupił na sobie najszerszą z wyobrażalnych publiczność, chociaż ani przez chwilę nie pozostawała ona $\mathrm{w}$ żadnym bezpośrednim, zwłaszcza zmysłowym, kontakcie z performerami. Performans wypraw polarnych nie był zatem ani widowiskiem, ani słuchowiskiem - nie był w ogóle żadnym ,zmysłowiskiem”. Publiczność dowiadywała się o jego rozpoczęciu. Potem następowała, czasami aż kilkuletnia, pustka (którą można było wypełniać własnymi fantazjami na temat tego, co tam właśnie się dzieje). Wreszcie zaś poznawano performans ex post z rysunków i pisemnych relacji rozmaitego rodzaju; można rzec - z klasycznego zestawu mediów emblematu. Rzecz odbywała się więc wedle procedury opisanej tu wcześniej, tyle że publiczność zyskiwała dostęp do jej szczegółów dopiero w momencie, kiedy sam proces performatywny się zakończył, ustała jego „nażywość”, pozostał po nim ,suchy” emblemat.

Innymi słowy: gdy w XIX wieku ruszała wyprawa do bieguna, publiczność dowiadywała się o otwarciu przestrzeni emblematycznej. Potem nie miała w nią wglądu. Wreszcie otrzymywała pochodzący z niej emblemat. I mogła wyprowadzać sobie z niego dalej jakieś własne performanse, co na masową skalę czyniono. W Zjadaniu psów szczegółowo opisuję rozmaite tego wszystkiego przypadki, koleje, warianty, katastrofy i sukcesy. Podkreślam, jak ważna w ramach samego performansu była kreacja emblematu, który po nim pozostawał. Zatrzymuję się tam przy własnościach przestrzeni emblematycznej, mających szczególny związek $\mathrm{z}$ zasadniczym, fundamentalnym celem wszelkiego performansu: przetrwaniem.

Przetrwanie zaś może mieć rozmaite sensy i wymiary: od biologicznego przetrwania jednostki, rodu czy populacji, poprzez przetrwanie w obranym przez siebie zawodzie albo w grupie, do której się aspiruje, aż do kulturowego przetrwania jednostek, społeczności czy całych etnosów. W każdym z tych wymiarów przetrwaniu służy performans, który rozgrywa się w przestrzeni emblematycznej.

Osobno trzeba by omówić szczegółowe związki emblematu z ,performansem kulturowym" i charakteryzować przestrzeń emblematyczną w tym ostatnim. Dla rozważań tutaj najistotniejsze jest natomiast, że owe dawne wyprawy polarne stanowiły przykład „teatru społecznego" w innym jeszcze, może metaforycznym, znaczeniu: pewnego zajścia, które ma publiczność. Ma ono „widzów”, „słuchaczy” - lub właśnie ową ,publiczność”, która nie obcuje z nim żadnymi ze zmysłów, ledwie dowiaduje się o nim dzięki środkom emblematycznym. Ma może „świadków”. Nie w potocznym jednak, przyjętym zwłaszcza w sądownictwie znaczeniu: ludzi, którzy byli tam i wtedy, i doświadczyli zjawiska bezpośrednio zmysłami. Te wyprawy miały ,świadków”, czyli ludzi, w których świadomości zdarzenie zaistniało na bieżąco, najwcześniej jak tylko mogło, w miarę swego stawania się. I zaistniało najprostszą możliwą drogą, która w tym wypadku wiodła 
poprzez emblematy. W tym sensie dziś pełnoletni w większości byliśmy świadkami zamachu na World Trade Centre, niezależnie od tego, czy byliśmy akurat na Manhattanie, i nawet niezależnie od tego, czy w ciągu owych paru krytycznych godzin zdarzyło nam się znaleźć przed telewizorami. W chwili zaś, kiedy to piszę, wszyscy jesteśmy świadkami pandemii Covid-19, chociażby nawet ktoś - jak ja nie widział na własne oczy nikogo chorego.

Może najlepiej pasuje tu zarzucone już w polszczyźnie określenie: jesteśmy tej pandemii przytomni. Podobnie przytomna wyprawom polarnym była ich publiczność półtora wieku temu.

\section{EMBLEMAT, TEATR, SPOŁECZEŃSTWO}

Dwa rozumienia „teatru społecznego” spotykają się gdzieś w środku, w continuum, na określenie którego warto może przywołać dawny termin Andrzeja Falkiewicza - „Teatr Społeczeństwo"65. Granica pomiędzy aktorami, chcącymi nadać swej grze jak najszerszy społeczny rezonans, a aktywistami, dla dobra sprawy teatralizującymi własne działania, bywa płynna i czasem nieuchwytna (kim w ostatecznym rachunku był Augusto Boal?). Wydaje się natomiast, że droga do „Zaistnienia” w świadomości społecznej wiedzie właśnie poprzez przestrzeń emblematyczną. I prowadzi do utworzenia w słowie, geście i obrazie skutecznych, fortunnych emblematów - wskazujących bądź na osobę samego performera jako Osobliwość, bądź na sprawę, z którą performer się utożsamia.

Co pojawia się natychmiast w naszych głowach, kiedy słyszymy nazwiska z naprędce zestawionej, różnorodnej listy osób o skrajnie odmiennych motywacjach, osiągnięciach i zamiarach: Siddharty Buddy, Diogenesa z Synopy, Herostratesa, świętego Franciszka, Napoleona Bonaparte, Mahatmy Gandhiego, Martina Luthera Kinga, Josepha Beuysa, Osamy bin Ladena? Czy nie emblematy ich działań? Tych ludzi łączy tylko to, że każdy z nich własnym wysiłkiem otworzył pewną przestrzeń emblematyczną: prostą lub skomplikowaną, o większej lub mniejszej liczbie wymiarów i sensów, najrozmaiciej wreszcie ocenianą przez współczesnych i przez potomnych. Każdy z nich właśnie poprzez tę przestrzeń ustanowił się w świadomości ogółu na trwałe.

$\mathrm{W}$ ostatecznym więc rozrachunku, jak się zdaje, różnica pomiędzy przestrzenią emblematyczną tworzoną w ramach specjalnych instytucji, zazwyczaj zwanych teatrami, i przestrzenią, którą samorzutnie tworzą działania przeróżnych społecznych i życiowych performerów, polega na tym, że do teatru rozmyślnie udajemy się po to, aby w przestrzeni emblematycznej się znaleźć i skorzystać z jej

65 Por. A. Falkiewicz, Teatr, społeczeństwo, Wrocław 1980. 
dobrodziejstw; jesteśmy rozczarowani, kiedy nam jej teatr nie otworzy. W życiu codziennym czy społecznym natomiast wypatrujemy tych przestrzeni, gdyż mogą one i próbują zawiązać się wszędzie. Zauważamy, kiedy to gdzieś się uda; zauważamy tych, którym uda się je zawiązać, osiągnąć i rozewrzeć, oraz tych, którym uda się w taką przestrzeń wejść, by nią zawładnąć albo się w niej zagubić. Niezależnie od charakteru tej przestrzeni każda z nich jest dla ogółu darem. Świadectwem życia po prostu.

Przy czym rzecz jasna: „ogół” - w którego świadomości zostają ludzkie czy dramatyczne postacie - to powiedziane $\mathrm{z}$ rozmachem. Nie trzeba chyba dodawać, że „sukcesu” czy „fortunności” emblematu nie mierzy się w kategoriach bezwzględnych. To, co jednym otwiera przestrzeń zapierających dech w piersiach perspektyw najrzeczywistszej Enigmy, dla innych stanowić może kicz lub banał, dzieło manipulacji lub samoułudy. Skuteczność emblematu jest relatywna, jego klęska także. W ostatnich latach w szerokich kręgach społeczeństw stopniowo ożywiały się dawno skompromitowane i, jak się nam zdawało, odesłane do archiwum emblematy totalitaryzmu. Wchodziły ponownie w obieg, objawiły inspirującą moc, dziś ku zgrozie jednych, upojeniu drugich, ustanawiają własne przestrzenie intensywnego performansu, zaskakującego i uderzającego swą skutecznością.

\section{PODSUMOWANIE}

Co pozostaje $\mathrm{z}$ dzieła teatralnego w najdalszym społecznym obiegu - tam, gdzie nie sięga już żadna żywa pamięć świadków czy uczestników tego dzieła? Wydaje się, że to, z czego potem można rozniecić nowe dzieło teatralne: emblemat.

Emblemat stanowi residuum, materialny zaczyn i ostateczny trwały produkt ludzkich procesów performatywnych, zachodzących między innymi właśnie w teatrze. Przez to stanowi główne medium ich społecznego przekazu - zwłaszcza przekazu na daleki dystans, kiedy to zanika wszelki żywy i bezpośredni kontakt odbiorców z samym teatralnym przedstawieniem.

W ślad za tym idzie przypuszczenie, które usiłuję poprzeć paroma historycznymi przykładami, że teatr bardziej nastawiony na społeczną misję chętnie sięga do środków sztuki emblematu, jawnie z nich korzysta i pielęgnuje tę relację.

Następnie przyglądam się kwestii „fortunności” emblematu, rozumianej w świetle poprzednich rozważań jako zdolność ewokowania żywego performansu (który z kolei o tyle byłby fortunny, o ile zdoła wytworzyć trwale intrygujący emblemat).

Wreszcie wprowadzam tytułowe pojęcie „,przestrzeni emblematycznej” - abstrakcyjnej kategorialnej przestrzeni, której wymiary wstępnie zapisane są w emblematach, stanowiących zaczyn zachodzącego w niej performansu. Performans 
ją ustanawia i przekształca; jest to przestrzeń intensywnej transformacji kategorialnej. Ostateczne wymiary po wszelkich przekształceniach notuje i utrwala emblemat, który powstał w wyniku odbytego w niej performansu.

Mówiąc obrazowo: przestrzeń emblematyczna otwiera się w powszechnej świadomości jako scena, na której rozgrywa się przyciągający uwagę społeczności performans. Instytucja teatru jawi się zaś jako miejsce, w którym na mocy umowy społecznej takie przestrzenie tworzy się programowo. Na udanym ich tworzeniu polega sukces i obowiązek teatru. W życiu powszednim natomiast przestrzenie emblematyczne tworzą się samorzutnie wskutek działań zbiorowości (jako emanacja jej oczekiwań lub nadziei) albo poprzez działania przyciągających publiczną uwagę jednostek; zachodzące w tych przestrzeniach działania zyskują rangę performansu społecznego. 